\title{
EDITORIAL
}

\section{Who can pay for innovative medicines?}

\author{
Stefaan Decramer* and Marc Decramer ${ }^{\#}$
}

I nnovative medicines are of vital importance to the patients affected with one of the many acute or chronic illnesses, for which current treatments are often suboptimal. In particular chronic non-communicable diseases are becoming more prevalent, and this is even seen as a real crisis requiring United Nations action [1, 2]. It is widely known that, although the investments of the pharmaceutical industry in research and development (R\&D) have increased substantially in the past decade, the number of innovative medicines that were registered with the US Food and Drug Administration and the European Medicines Agency has decreased over the same time period $[3,4]$. A prime example is the respiratory field in which only nine new drugs have been developed over the past 40 years, four of which were for one particular disease, i.e. primary pulmonary hypertension [5]. Despite R\&D spending at a high of $18 \%$ of revenues, the R\&D productivity of the big pharmaceutical companies declined by $20 \%$ between 2001 and 2007 [6]. The innovation pipeline remains anaemic. A further thread is that shareholders are not willing to invest more money in R\&D, without tangible success [3].

A number of new R\&D models have been developed to attempt to mitigate the problem of anaemic pipelines [6]. Some large pharmaceutical companies have restructured their R\&D centres in order to create the spirit of biotech $R \& D$ culture. Other companies have acquired smaller companies that were left as stand-alone units operating independently, with the general idea of replicating an entrepreneurial spirit in their large organisation; an example of this is the interaction between Roche and Genentech. Some companies broke down barriers to share intellectual property. The European Union Innovative Medicines Initiative is an example of a programme where companies work together and share knowledge in the development of new medicines [7]. Finally, some companies partnered with leading academic institutions to promote innovation from basic research, a practice that has led to the development of a surprisingly high number of new drugs, vaccines and indications [8].

Is it feasible to rely more on Public Sector Research Institutions (PSRIs) for drug discovery? The global pharmaceutical market reached a level of 875 billion USD in 2010 and is expected to reach over 1 trillion USD in 2014 [9]. Currently, the top 50 pharmaceutical companies spend an average of $18 \%$ of total revenues in R\&D, yielding an annual budget of 96 billion USD. Even if this is

*Faculty of Economics and Business, University of Leuven, Leuven, and ${ }^{*}$ Respiratory Division, Dept of Clinical and Experimental Medicine, University of Leuven, Leuven, Belgium.

CORRESPONDENCE: M. Decramer, Respiratory Division, Dept of Clinical and Experimental Medicine, University of Leuven, Herestraat 49,3000 Leuven, Belgium. E-mail: marc.decramer@ uzleuven.be slightly overestimated, it is still a massive amount of funding. Assuming that about $25 \%$ of that budget is devoted to drug discovery [10], global pharma would currently spend 32 billion USD on it. Hence, PSRIs would need a similar budget to intensify their efforts in drug discovery, which appears in the present context to be problematic. Most countries do not have sufficient research funds to approach this order of magnitude, and even for the USA this would correspond to the entire National Institutes of Health (NIH) annual budget! The NIH-proposed new drug development centre, although certainly timely and necessary, is expected to attract 1 billion USD in funding [11], presumably spread over several years. The European Union spent $€ 54$ billion in the FP-7 programme of which only $11 \%$ was invested in health research, amounting to $€ 6$ billion, over a 4 -year period [4]. Assuming that about 3\% of this budget would be spent on drug discovery, this only represents $0.05 \%$ of the funds presently spent by the pharmaceutical industry.

Although it appears at first sight not feasible that government agencies would entirely support drug discovery, another important element needs to be considered. Most medicines are reimbursed by health authorities in different countries. In Europe, an average of about $80 \%$ of the cost is borne by the healthcare systems [12]. Hence, if governments would largely pay for drug discovery directly, the cost of drugs could be reduced because the development cost would now no longer be borne by the companies alone, but instead be shared between the companies and the governments of all nations around the world. Moreover, this could direct drug research better towards public health priorities and no longer towards the financial and marketing needs of the pharmaceutical industry, alone. In addition, research agendas could be synchronised, no longer generating double costs. The industry could then buy licenses for the promising drugs "risk-free", and develop them further clinically and market them, while governments could recuperate some of their investment costs by selling these licenses. If in this concept, the price of medications would drop by $20 \%$, which appears entirely reasonable (given that the price of generic medicines is about $30-80 \%$ less than their original equivalents), a budget of about 150 billion USD would be mobilised (given that the total global revenues are 875 billion to 1 trillion USD). This appears more than sufficient to bring more innovation to the medicines sector. However, two additional conditions would need to be fulfilled. First, supranational coordination of the research efforts through the European Union, United Nations, World Health Organization or similar organisations would be mandatory, as efforts need to be concerted on a larger scale. Secondly, savings made by governments by the reduction of the costs of medicines would need to be invested in research and not spent on other governmental priorities. It is clear that 
the latter two conditions are challenging in the present financial and political context, but challenges may be overcome.

\section{STATEMENT OF INTEREST}

A statement of interest for M. Decramer can be found at www.erj. ersjournals.com/site/misc/statements.xhtml

\section{REFERENCES}

1 Beaglehole R, Bonita R, Horton R, et al. Priority actions for the noncommunicable disease crisis. Lancet 2011; 377: 1438-1447.

2 Beaglehole R, Bonita R, Alleyne G, et al. UN high-level meeting on non-communicable diseases questions. Lancet 2011; 378: 449-455.

3 The Lancet. Where will new drugs come from? Lancet 2011; 377: 97.

4 Paul SM, Mytelka DS, Dunwiddie CT, et al. How to improve R\&D productivity: the pharmaceutical industry's grand challenge. Nature Reviews 2010; 9: 203-214.

5 Decramer M, Sibille Y, eds. European Respiratory Roadmap. Lausanne, European Respiratory Society, 2011. Available from: www.ersroadmap.org
6 IMAP: Pharmaceuticals and Biotech Industry Global Report 2011. IMAP, 2011. Available from: www.imap.com

7 Kamel N, Compton C, Middelveld R, et al. The Innovative Medicines Initiative (IMI): a new opportunity for scientific collaboration between academia and industry at the European level. Eur Respir J 2008; 31: 924-926.

8 Stevens AJ, Jensen JJ, Wyller K, et al. The role of public-sector research in the discovery of drugs and vaccines. N Eng J Med 2011; 364: 535-541.

9 Behnke N, Hueltenschmidt N. Changing Pharma's Innovation DNA. Boston, Bain and Company, 2010.

10 Pharmaceutical Research and Manufacturers of America: Pharmaceutical Industry Profile 2012. Washington, PhRMA, 2012. Available from: www.phrma.org

11 Bristol N. NIH proposes new drug development center. Lancet 2011; 377: 705-706.

12 Kanavos P, Vandoros S, Irwin R, et al. Differences in Costs of and Access to Pharmaceutical Products in the EU 2011. Brussels, European Parliament, 2011. Available from: www.europarl.europa. $\mathrm{eu} /$ activities $/$ committees/studies.do?language $=\mathrm{EN}$ 